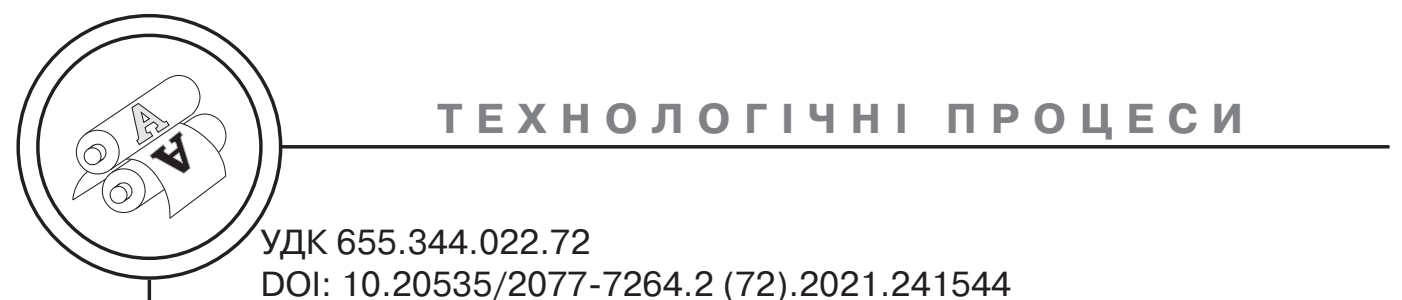

DOI: $10.20535 / 2077-7264.2$ (72).2021.241544

() С. Ф. Гавенко, Д-р техн. наук, проф., В. В. Бернацек, канд. техн. наук, доц., М. Т. Лабецька, канд. техн. наук, старш. викл., Українська академія друкарства, Львів, Україна

\title{
ДОСЛІДЖЕННЯ ВПЛИВУ \\ ТИПУ ЗВОЛОЖУВАЛЬНИХ СИСТЕМ В ОФСЕТНОМУ ДРУЦІ НА ЯКІСТЬ ВІДБИТКІВ
}

\begin{abstract}
У роботі представлено короткий аналіз та класифікація відомих методів нанесення зволожувального розчину, а також наведено результати експериментальних досліджень впливу технологічних параметрів друкування, а саме зміни типу зволожувального апарату та властивостей задруковуваного матеріалу на якість та точність відтворення кольорового зображення шляхом побудови графічних залежностей та визначення репродукційнографічних показників офсетних відбитків.
\end{abstract}

Ключові слова: офсетний друк; відбиток; зволожувальний апарат; папір; якість; оптична густина; градаційна передача; тоновідтворення.

Постановка проблеми

Сьогодні офсетний друк зберігає свої переваги над іншими технологіями репродукування. Так, основними атрибутами офсету $є$ гнучкі виробничі варіанти і відносно економічне виробництво друкованої продукції високої якості для широкого діапазону накладів. Машини офсетного друку повинні забезпечувати динамічний та специфічний складний процес друку за участю декількох матеріальних потоків (зволожувальний розчин, фарба, папір, повітря) в контрольованийта надійний спосіб [1-3].
Система зволоження в плоскому офсетному друці $є$ унікальним вузлом, який забезпечує рівномірне, стабільне нанесення зволожувального розчину на друкарську форму і дозволяє управляти балансом «фарба-вода» в процесі друкування задля отримання поліграфічної продукції високої якості. 3 цією метою склад сучасних концентратів зволожувальних розчинів та конструкції апаратів зволоження для офсетного друку постійно удосконалюються [4-6].

У даний час на поліграфічному ринку зустрічається широкий асортимент конфігурацій зволожу-

() Автор(и) 2021. Видавець КПІ ім. Ігоря Сікорського.

CC BY 4.0 (https://creativecommons.org/licenses/by/4.0/). 
вальних апаратів. Залежно від особливостей будови та конструкції системи зволоження поділяються:

- за методом подачі розчину контактний, безконтактний (розпилення);

- за типом потоку - безперервні, дискретні;

- за спрямованістю потоку одинарні, двонаправлені;

- за шляхом потоку струменя розчину - на форму, фарбовий апарат, комбіновано.

Якість відбитків офсетного друку безпосередньо залежить від особливостей взаємодії фарби та зволожувального розчину, стабільності їх балансу, точне регулювання якого забезпечує тонкий і рівномірний розподіл плівки зволожувального розчину на друкарській формі. Конструкції сучасних систем зволоження повинні гарантувати точну подачу зволожувального розчину на пробільні елементи друкарської форми в кількості еквівалентній її особливостям при заданій швидкості роботи машини [7].

\section{Мета роботи}

Визначення впливу технологічних параметрів процесу зволоження з використанням різних зволожувальних апаратів на якість офсетних відбитків.

\section{Об'єкти і методи дослідження}

Об'єктами дослідження було обрано найбільш розповсюджені при виготовленні друкованої продукції матеріали: крейдований матовий і глянцевий папір марки Vega Gloss масою 1 м² 115 г; комплект фарб фірми Huber серії Resista. Цифрова кольоропроба оригінал-макету із зображеною широкою гаммою кольорів була віддрукована на цифровій машині Xerox 700i Digital Color Press, а друкування аналогової кольоропроби здійснювалось на друкарській офсетній машині Heidelberg GTO 52 із зволожувальним апаратом:

№ 1 - Kompac III;

№ 2 - Alcolor;

№ 3 - 3 чохловим зволоженням.

Сучасний автоматичний зволожувальний апарат Varn Kompac III сконструйований, як апарат для друку без ізопропилового спирту (IPA), здатний строго дозувати подачу зволожувального розчину на друкарську форму. У нормальному стані валики цієї системи вкриті шаром емульсії (шаром фарби). В «імпровізованому» кориті, утвореному двома валиками системи, утворюється однорідна емульсія води і фарби. При обертанні цих валиків, емульсія проходить через зазор між ними, і накочується на друкарську форму. До переваг даного зволожувального апарату слід віднести: відсутність чорнишів та різних відтінків при друці, вапнякового залишку на валиках, спирту, неприємного запаху, стабільність подачі $\mathrm{pH}$, вихід на тиражний аркуш вже через 5-7 відбитків, економія паперу до 15 \% при приладці.

Зволожувальна система Неіdelberg Alcolor працює за принципом подачі тонкого шару вологи накочувальним валиком спочатку на форму, а потім на перший накочувальний валик фарбового апарату. Такий спосіб нанесення зволожувального розчину, запатентований фірмою Heidelberg, сприяє швидкому насиченню 
вологою форми завдяки утворенню збалансованого складу водно-фарбової емульсії, що дозволяє в процесі роботи вже через 3-5 циклів оперативно вивести друкарську машину на режим друкування з мінімальним технічними потребами. При друкуванні накладу, де не потрібна велика кількість вологи, є можливість відставити проміжний валик від фарбового апарату.

Зволожувальний апарат з чохлами (чохлове зволоження) відноситься до традиційних класичних пристроїв, в яких передавальний валик здійснює коливальнопоступальний рух, періодично торкаючись дозувального цилін- дру для перенесення певної кількості зволожувального розчину. Валики вкриті спеціальними чохлами, які виконують демпферну функцію, акумулюючи і розподіляючи зволожувальний розчин між інтервалами контактів і переносним валиком [8-11].

Засобом для оцінювання якості відбитків були тестові шкали для визначення роздільної здатності та лініатури друкування, з полями півтонів і тонів, побудовані для CMYK-кольорів та ряд шкал для контролю якості офсетного способу друку Ugra/Fogra Digital Print Scale Control, які включають елементи ковзання, розтискування, відтворення дріб-

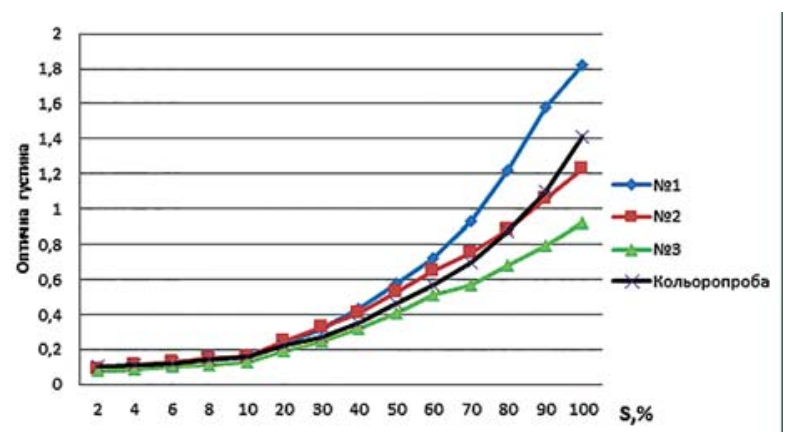

a

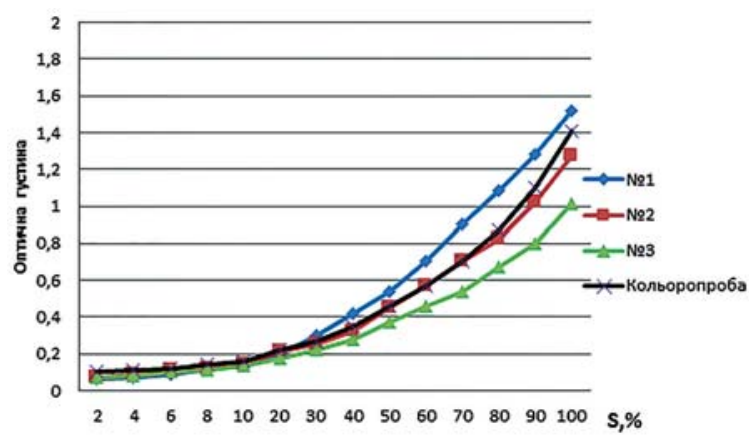

б

Рис. 1. Градаційна передача блакитної фарби (Cyan): a - матовий, б - глянцевий папір, 175 Ірі; № 1-3 - типи зволожувальних апаратів 
них деталей, радіальної міри, поля півтонів, суміщення фарб, текстові елементи тощо [12]. Для вимірювання оптичної густини використовували спектроколориметр Gretag SPM 50. Опрацювання отриманих результатів експериментальних досліджень проводилось з використанням пакету програмного забезпечення Microsoft Office Excel 2010.

\section{Результати проведених досліджень}

Оцінювання якості та точності відтворення кольорового зображення, віддрукованого офсетним способом друку на різних матеріалах при зміні технологічних па- раметрів зволожувальних систем проведено шляхом побудови графічних залежностей зміни градаційної передачі фарб досліджуваних взірців і кольоропроби. На рис. 1-4 представлено градаційну передачу блакитної, пурпурної, жовтої та чорної фарб на матовому та глянцевому папері з використанням трьох видів зволожувальних систем.

Як показує аналіз отриманих графічних залежностей градаційної передачі фарб на офсетних відбитках на матовому та глянцевому паперах при використанні різних зволожувальних систем, тільки для блакитної фарби градаційна передача на всіх досліджуваних

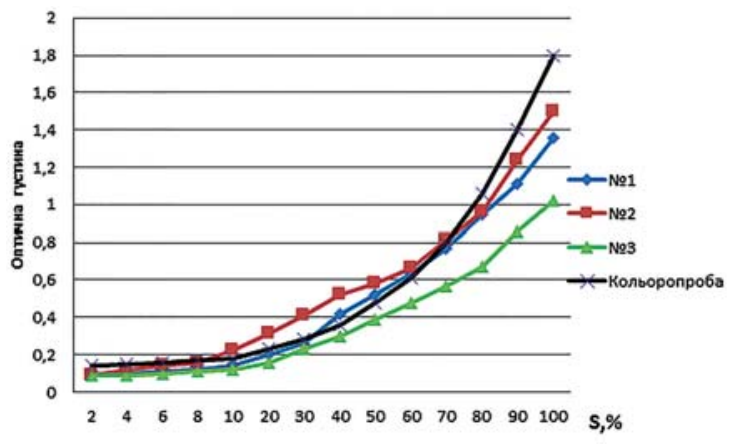

a

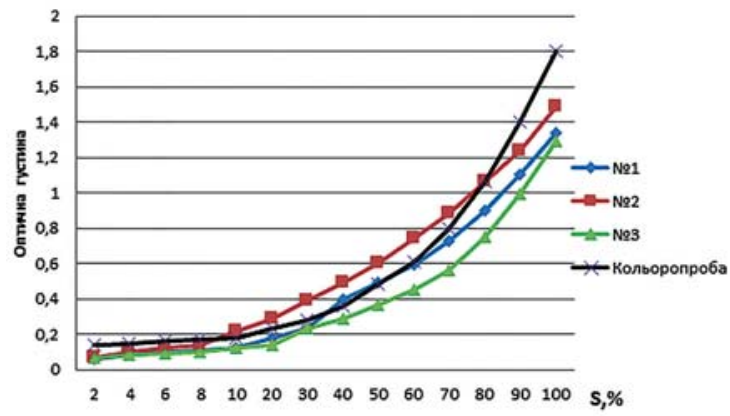

б

Рис. 2. Градаційна передача пурпурної фарби (Magenta): a - матовий, б - глянцевий папір, 175 Ірі; № 1-3 - типи зволожувальних апаратів 
взірцях (рис. 1) відповідає кольоропробі в світлих ділянках. У півтонах і в темних ділянках оптична густина зростає при використанні зволожувальної системи № 1. При застосуванні зволожувальних систем № 2 і № 3 оптична густина на відбитках спадає, починаючи з півтонів і, закінчуючи темними ділянками зображень. Найбільш наближеною до кольоропроби була оптична густина на відбитках досліджуваних паперів при використанні зволожувальної системи № 2.

На рис. 2 спостерігається незначне зростання оптичної густини для пурпурної фарби (зволожу- вальний апарат № 2), починаючи 3 поля $10 \%$. Аналіз відбитків на крейдованому і матовому паперах показав зниження оптичних густин для пурпурної фарби при використанні зволожувальних систем № 1 і № 3. Представлені на рис. 2 значення оптичних густин відповідають значенням кольоропроби в півтонах і спостерігається спадання оптичних густин на відбитках в темних ділянках, а також зменшення площі растрових елементів при використанні зволожувальної системи № 1 і № 2. При використанні зволожувальної системи № 3 для двох видів паперу спостері-

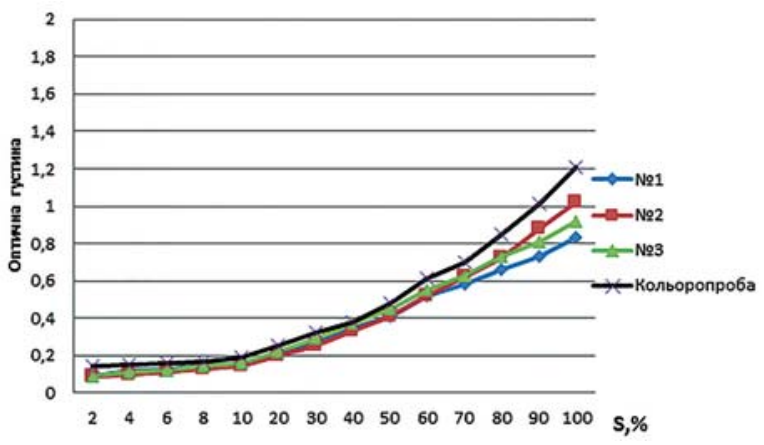

a

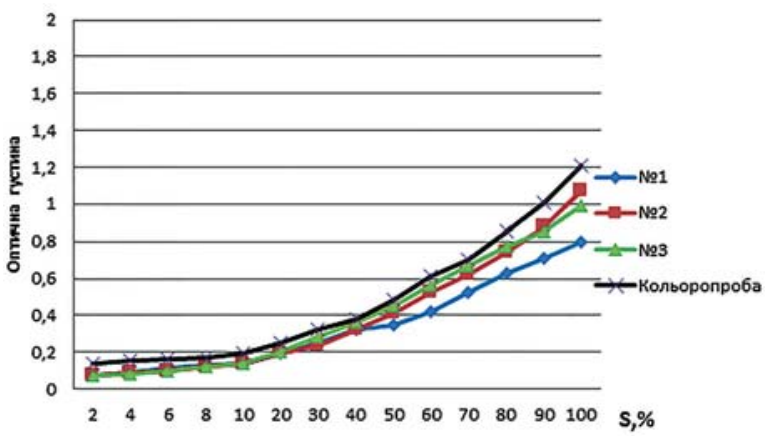

б

Рис. 3. Градаційна передача жовтої фарби (Yellow): a - матовий, б - глянцевий папір, 175 Ірі; № 1-3 - типи зволожувальних апаратів 
гається значне зменшення густини, починаючи 3 півтонів i, закінчуючи темними ділянками. Аналіз досліджень показав, що градаційна передача пурпурної фарби на відбитку з глянцевого паперу (рис. 2, б) є стабільною на всій тестовій контрольній шкалі.

Графічні залежності передачі жовтої фарби, представлені на рис. 3, схожі між собою, а саме: у світлих ділянках і півтонах оптичні густини всіх досліджуваних взірців відповідають кольоропробі, тільки на рис. 3, б, починаючи з поля $50 \%$, помітне зменшення площі елементів при використанні зволожувальної системи № 1.
Аналіз друкарських відбитків, утворених чорною контурною фарбою, показує стабільну градаційну передачу площі растрових елементів в світлих ділянках. Починаючи з ділянок півтонів i, закінчуючи темними ділянками оптична густина на відбитку зростає і на ділянці 100 \% співпадає з кольоропробою (при використанні зволожувальних систем № 1 і № 3). Незначні відхилення значень оптичних густин від еталонного взірця спостерігаються на відбитках з крейдованого і матового паперу при використанні зволожувальної системи № 2.

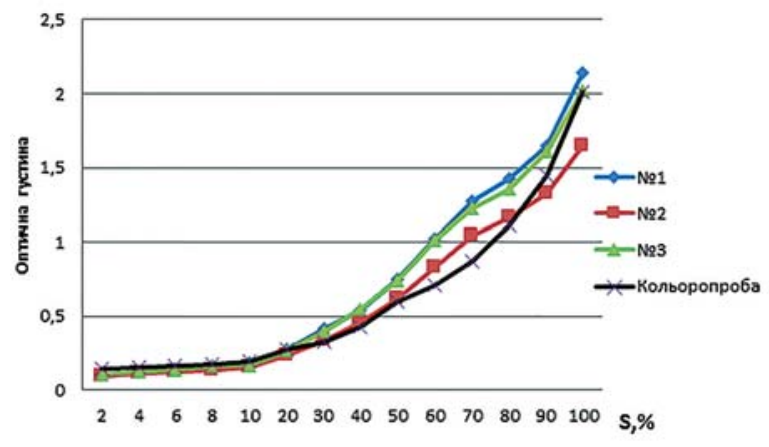

a

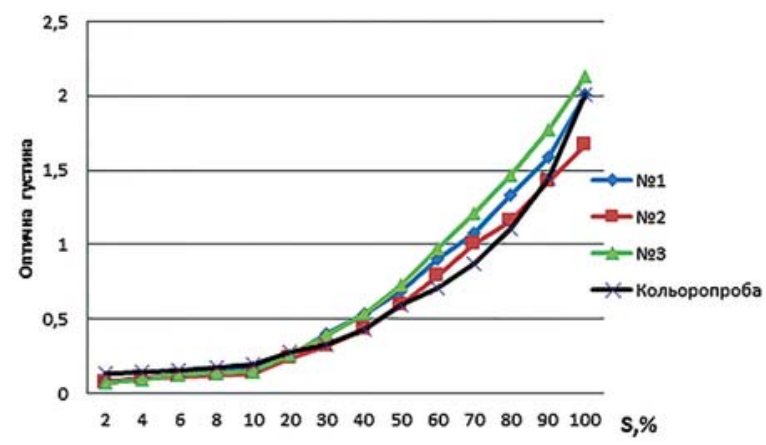

б

Рис. 4. Градаційна передача чорної фарби (Black): a - матовий, б - глянцевий папір, 175 Ір; № 1-3 - типи зволожувальних апаратів 


\section{Висновки}

Високі показники якості відбитків в офсетному друці забезпечуються підтриманням стабільності стандартного друкарського середовища - балансу фарбазволожуючий розчин. Процес зволоження відіграє вирішальну роль в досягненні оптимальних показників якості відбитків офсетного друку. Тому встановлення впливу типу зволожувального апарату на точність відтворення кольорового зображення є особливо важливим та актуальним завданням.

В результаті проведення експериментальних досліджень встановлено, що показники оптичної густини в світлих ділянках на відбитках з крейдованого і матово- го паперу, отриманих в офсетній друкарській машині Heidelberg GTO-52 із зволожувальними апаратами Kompac III, Alcolor та звичайним чохловим зволоженням, відповідають показникам кольоропроби. У півтонах найбільш нестабільна передача градацій зафіксована для фарби Cyan i Black при використанні зволожувального апарату № 1. В темних ділянках стабільну передачу для фарб Magenta i Black на відбитку забезпечує зволожувальний апарат № 2. Аналіз отриманих результатів показав, що зволожувальний апарат типу Alcolor забезпечує найбільш наближені до кольоропроби репродукційно-графічні показники на матових і глянцевих видах паперу.

\section{Список використаної літератури}

1. Зоренко Я. В. Технології репродукування плоским офсетним друком / Я. В. Зоренко: моногр. К.: ВПЦ «Київський університет», 2015. 176 с.

2. Чепурна К. О. Дослідження впливу друкарсько-технічних властивостей фарбових валиків на оптичні показники відбитків / К. О. Чепурна // Поліграфія і видавнича справа. 2012. № 3. С. 74-79.

3. Скиба В. М. Технологічні основи тиражної стабільності друкарських форм / В. М. Скиба: моногр. К.: ВПЦ «Київський університет», 2015. 148 с.

4. Kushlyk B. Adjustment of Ink and Water Supply in Offset Printing / B. Kushlyk // Journal of Materials Science and Engineering. USA, 2013. Issue \# 3(8). pp. 545-549.

5. Нечипоренко Н. А. Выбор концентрата и определение оптимальной рецептуры увлажняющего раствора для листовой офсетной печати / Н. А. Нечипоренко, А. В. Бердовщикова, М. А. Бозоян // Известия высших учебных заведений. Проблемы полиграфии и издательского дела. 2013. № 6. С. $30-42$.

6. Орлова Е. Ю. Исследование параметров пленочных увлажняющих аппаратов / Е. Ю. Орлова: моногр. Москва: МГУП, 2013. 250 с.

7. Manisha S. Type of dampening system and overall equipment effectiveness / Manisha S. // Deshpande International Journal of Advanced Engineering Technology IJAET. 2011. Vol. II (Issue IV). pp. 114-117.

8. Rossitza S. Offset Printing without Isopropyl Alcohol in Damping Solution / Sardjeva Rossitza // Energy Procedia. 2015. T. 74. pp. 690-698. Retrieved from https://www.sciencedirect.com/science/article/pii/S1876610215015726.

9. Вулканов Е. В. Исследование подачи увлажняющих растворов с малым содержанием изопропилового спирта питающей группой увлажняющего аппарата / Е. В. Вулканов, Е. Ю. Орлова // Весник Московского государственного университета печати. 2014. № 1. С. 144-147. 
10. «Безалкогольный» увлажняющий аппарат [Электронный ресурс] Информационный ресурс iPages.ru. Режим доступа: http://www.ipages.ru/ index.php?ref_item id=5489\&ref_dl=1.

11. Системы дозирования спирта alcosmart AZR [Электронный ресурс] / Официальный сайт MacHOUSE. Режим доступа: http://machouse.ua/print/ catalog/technotrans/humidification/dosing-systems/21816.html.

12. ISO 12647-2: 2004 / Amd 1: 2007 - Управління процесами виробництва кольороподілених напівтонових зображень, пробних і накладних відбитків - Частина 2: Офсетний аркушевий друк.

\section{References}

1. Zorenko, Ya. V. (2015). Tekhnolohii reprodukuvannia ploskym ofsetnym drukom [Technologies of Reproduction by Flat Offset Printing]. Kyiv: VPTs 'Kyivskyi universytet', 176 p. [in Ukrainian].

2. Chepurna, K. O. (2012). Doslidzhennia vplyvu drukarsko-tekhnichnykh vlastyvostei farbovykh valykiv na optychni pokaznyky vidbytkiv [Investigation of the Influence of Printing and Technical Properties of Ink Rollers on Optical Indicators of Imprints]. Polihrafiia i vydavnycha sprava, 3, 74-79 [in Ukrainian].

3. Skyba, V. M. (2015). Tekhnolohichni osnovy tyrazhnoi stabilnosti drukarskykh form [Technological Bases of Circulation Stability of Printing Forms]. Kyiv: VPTs 'Kyivskyi universytet', 148 p. [in Ukrainian].

4. Kushlyk, B. (2013). Adjustment of Ink and Water Supply in Offset Printing. Journal of Materials Science and Engineering, 3(8), 545-549 [in English].

5. Nechiporenko, N. A., Berdovshhikova, A. V., \& Bozojan, M. A. (2013). Vybor koncentrata i opredelenie optimal'noj receptury uvlazhnjajushhego rastvora dlja listovoj ofsetnoj pechati [Choosing a Concentrate and Determining the Optimal Formulation of a Dampening Solution for Sheetfed Offset Printing]. Izvestija vysshih uchebnyh zavedenij. Problemy poligrafii i izdatel'skogo dela, 6, 30-42 [in Russian].

6. Orlova, E. J. (2013). Issledovanie parametrov plenochnyh uvlazhnjajushhih apparatov [Investigation of the Parameters of Film Dampening Devices]. Moscow: MGUP, 250 p. [in Russian].

7. Manisha, S. (2011). Type of dampening system and overall equipment effectiveness. Deshpande International Journal of Advanced Engineering Technology (IJAET), Vol. II (Issue IV), 114-117 [in English].

8. Rossitza, S. (2015). Offset Printing without Isopropyl Alcohol in Damping Solution. Energy Procedia, T. 74, 690-698. Retrieved from https://www.sciencedirect.com/science/article/pii/S1876610215015726 [in English].

9. Vulkanov, E. V., \& Orlova, E. J. (2014). Issledovanie podachi uvlazhnjajushhih rastvorov s malym soderzhaniem izopropilovogo spirta pitajushhej gruppoj uvlazhnjajushhego apparata [Study of the Supply of Moisturizing Solutions with a Low Content of Isopropyl Alcohol by the Feeding Group of the Humidifying Apparatus]. Vesnik Moskovskogo gosudarstvennogo universiteta pechati, 1, 144-147 [in Russian].

10. 'Bezalkogol'nyj' uvlazhnjajushhij aparat ['Non-alcoholic' Humidifier]. Retrieved from: http://www.ipages.ru/index.php?ref_item_id=5489\&ref_dl=1 [in Russian].

11. Sistemy dozirovanija spirta alcosmart AZR [Alcohol Dosing Systems alcosmart AZR]. Retrieved from http://machouse.ua/print/catalog/technotrans/humidification/dosing-systems/21816.html [in Russian].

12. ISO 12647-2: 2004 / Amd 1: 2007 - Upravlinnia protsesamy vyrobnytstva koloropodilenykh napivtonovykh zobrazhen, probnykh i nakladnykh vidbytkiv - 
Chastyna 2: Ofsetnyi arkushevyi druk [Management of Production of ColorSeparated Halftone Images, Trial and Overlay Imprints - Part 2: Offset Sheet Printing]. [in Ukrainian].

In this paper we present a brief analysis and classification of known methods of applying wetting solution, and also the results of experimental studies of the influence of technological parameters of printing, namely changes in the type of wetting apparatus and properties of printed material on the quality and accuracy of reproduction of the color image by construction of graphic dependences and definition of reproduction-graphic indicators of offset imprints.

Keywords: offset printing; imprint; humidifying device; paper; quality; optical density; gradation transmission; tone reproduction.

Надійшла до редакції 14.05.21 